Studia nad Autorytaryzmem i Totalitaryzmem 43, nr 4 Wrocław 2021

https://doi.org/10.19195/2300-7249.43.4.4

\author{
MONIKA CZECHOWSKA \\ ORCID: 0000-0001-8070-6094 \\ Uniwersytet Wrocławski \\ monika.czechowska@uwr.edu.pl
}

\title{
Konfiskata mienia obowiązująca na gruncie kodeksu karnego PRL jako instrument totalitarnego systemu komunistycznej dyktatury
}

\author{
Słowa kluczowe: prawo karne, konfiskata mienia, kodeks karny PRL, represja ekonomiczna, \\ walka z przeciwnikami politycznymi. \\ CONFISCATION OF PROPERTY IN FORCE UNDER THE CRIMINAL CODE \\ OF THE POLISH PEOPLE'S REPUBLIC AS AN INSTRUMENT \\ OF THE TOTALITARIAN SYSTEM OF COMMUNIST DICTATORSHIP
}

\begin{abstract}
Confiscation of property, understood as depriving the perpetrator of a crime (as well as third parties not involved in criminal practice) of all or part of their property, regardless of whether it was derived from criminal activity or was collected legally, is one of the most painful means of criminal law response in history. From the perspective of today's standards of human rights protection, it appears unacceptable and contrary to the guarantee function of criminal law. As the analysis of past regulations shows, this measure was used with pleasure in totalitarian states (for example in Nazi Germany and the Soviet Union) as an instrument of fighting political opponents, which was to occur through economic repression, often leading to material annihilation. Confiscation of property was also in force under the Criminal Code of the Polish People's Republic. The official ratio legis of this institution was seen in the fight against crime against social property. However, an analysis of the practical application of this institution leads to the conclusion that it was not the only goal of the then legislator. The aim of this article is therefore to analyze the institution of confiscation of property in force under the 1969 Criminal Code, and in the longer term to find an answer to the question of whether this regulation was an instrument of the totalitarian system of the communist dictatorship.
\end{abstract}

Keywords: criminal law, confiscation of property, Criminal Code of the Polish People's Republic, economic repression, fight against political opponents. 


\section{Wprowadzenie}

Konfiskata mienia jest jednym $\mathrm{z}$ najbardziej represyjnych środków reakcji karnej, polegającym na pozbawieniu sprawcy przestępstwa całości jego majątku niezależnie od tego, czy pochodził on z działalności przestępczej, czy też był mieniem zgromadzonym legalnie ${ }^{1}$. Jednocześnie instytucja ta stanowi jeden z najstarszych środków reakcji karnej, gdyż zabór majątku jako sankcja karna znany już był plemionom słowiańskim, które dopatrywały się w nim odwetu symbolicznego ${ }^{2}$. Środek ten z powodzeniem stosowany był także w średniowieczu i latach późniejszych. Wraz z rozwojem prawa karnego, jak również myśli oświeceniowej, konfiskatę mienia zaczęto postrzegać jako zbyt dolegliwy i restrykcyjny instrument, zwłaszcza w zakresie, w jakim pozwalał na pozbawianie majątku osób trzecich, które nie uczestniczyły w działalności przestępczej ${ }^{3}$. W Europie Zachodniej już w XIX wieku konfiskata mienia została w znacznej mierze wyparta przez mniej dolegliwy i zrelatywizowany do szkody przepadek narzędzi lub owoców przestępstwa $^{4}$. Sytuacja podobnie zresztą kształtowała się w prawodawstwie państw zaborczych obowiązującym na ziemiach polskich ${ }^{5}$. Również kodeks karny z 1932 roku nie przewidywał expressis verbis konfiskaty majątku lub jego części. Instytucja ta występowała jednak incydentalnie w ustawach szczególnych pod nazwą kary przepadku majątku ${ }^{6}$ i miała zastosowanie w wyjątkowych przypadkach - mowa tutaj na przykład o ustawie z dnia 23 czerwca 1939 roku o szczególnej odpowiedzialności karnej w przypadku zbiegostwa do nieprzyjaciela lub poza granice państwa ${ }^{7}$.

Co ciekawe, konfiskata mienia sensu stricto powróciła do katalogu sankcji karnych wraz z rozwojem państw totalitarnych, które wykorzystywały ten instrument do likwidacji wyimaginowanych wrogów władzy i przeciwników politycznych ${ }^{8}$. Cel ten miał być osiągnięty poprzez unicestwienie materialne. W polskim powojennym porządku prawnym kara konfiskaty mienia w ograniczonym zakresie również powróciła, jednakże miała zastosowanie głównie wobec sprawców zbrodni

${ }^{1}$ K. Buczkowski, Skuteczność odzyskiwania korzyści majątkowych uzyskanych przez sprawców przestęstwa - analiza przepadków orzeczonych na podstawie art. 45 k.k., „Prawo w Działaniu" 8, 2010, nr 8, s. 224.

2 I. Rzeplińska, Konfiskata mienia. Studium z historii polityki kryminalnej, Warszawa 1997, s. $90 \mathrm{n}$.

3 W. Cieślak et al., [w:] System prawa karnego, t. 6. Kary i inne środki reakcji prawnokarnej, red. M. Melezini, Warszawa 2016, s. 794.

${ }^{4}$ K. Postulski, M. Siwek, Przepadek w polskim prawie karnym, Warszawa 2004, s. 20.

5 W. Makowski, Prawo karne. Część ogólna. Wykład porównawczy prawa karnego austrjackiego, niemieckiego i rosyjskiego obowiazujacego w Polsce, Warszawa 1920, s. 386.

6 Przepadek przedmiotów i korzyści pochodzacych z przestęstwa, red. E.M. Guzik-Makaruk, Warszawa 2012.

7 Ustawa z dnia 23 czerwca 1939 roku o szczególnej odpowiedzialności karnej w przypadku zbiegostwa do nieprzyjaciela lub poza granice państwa (Dz.U. z 1939 r. Nr 57, poz. 367).

8 I. Rzeplińska, Sprawcy i kara. Skazani w PRL na karę konfiskaty mienia, „Biuletyn PTK” 2017, $\mathrm{nr} 24$, s. 73 . 
wojennych - mowa tutaj o dekrecie z dnia 31 sierpnia 1944 roku o wymiarze kary dla faszystowsko-hitlerowskich zbrodniarzy winnych zabójstw i znęcania się nad ludnością cywilną i jeńcami oraz dla zdrajców narodu polskiego ${ }^{9}$ oraz dekrecie z dnia 28 czerwca 1946 roku o odpowiedzialności karnej za odstępstwo od narodowości w czasie wojny $1939-1945^{10}$. Dopiero kodeks karny PRL, uchwalony 19 kwietnia 1969 roku (dalej: „kodeks karny PRL”, „k.k. PRL”, „kodeks karny z 1969"), wprowadził karę dodatkową konfiskaty mienia, rozumianą jako środek pozwalający na pozbawianie sprawców, jak również osób trzecich mienia zarówno pochodzącego z przestępstwa, jak i zgromadzonego legalnie. Zgodnie z oficjalnymi założeniami polityczno-kryminalnymi nowej kodyfikacji instrument ten miał na celu wyeliminowanie przestępczości uderzającej w mienie społeczne. Niemniej jednak - jeśli wziąć pod uwagę praktykę stosowania tego środka — nasuwa się wniosek, iż nie był to jedyny powód wprowadzenia rzeczonej regulacji.

Celem niniejszego artykułu jest zatem dokonanie analizy instytucji konfiskaty mienia obowiązującej na gruncie kodeksu karnego z 1969 roku, po to by w konsekwencji odnaleźć odpowiedź na pytanie, czy środek ten był narzędziem do walki z oponentami politycznymi i z tego też powodu (na mocy art. 2 ustawy z dnia 23 lutego 1990 roku o zmianie kodeksu karnego i niektórych innych ustaw, która to ustawa weszła w życie $\mathrm{z}$ dniem 28 marca 1990 roku $^{11}$ ) został usunięty z porządku prawnego jako niemożliwy do pogodzenia z międzynarodowymi standardami i prawami człowieka.

\section{Podstawy orzekania konfiskaty mienia w kodeksie karnym z 1969 roku}

Kodeks karny PRL przewidywał kary zasadnicze (art. 30 k.k. PRL) oraz kary dodatkowe (art. 38 k.k. PRL). Jedną z kar dodatkowych — obok pozbawienia praw publicznych, pozbawienia praw rodzicielskich lub opiekuńczych, zakazu zajmowania określonych stanowisk, zakazu wykonywania określonego zawodu lub prowadzenia określonej działalności, zakazu prowadzenia pojazdów mechanicznych lub innych pojazdów, przepadku rzeczy i podania wyroku do publicznej wiadomości — była kara konfiskaty mienia ${ }^{12}$, uzasadniana względami prewencji

${ }^{9}$ Dekret z dnia 31 sierpnia 1944 roku o wymiarze kary dla faszystowsko-hitlerowskich zbrodniarzy winnych zabójstw i znęcania się nad ludnością cywilną i jeńcami oraz dla zdrajców narodu polskiego (Dz.U. z 1946 r. Nr 69, poz. 377).

10 Dekret z dnia 28 czerwca 1946 roku o odpowiedzialności karnej za odstępstwo od narodowości w czasie wojny 1939-1945 r. (Dz.U. z 1946 r. Nr 41, poz. 237).

11 Ustawa z dnia 23 lutego 1990 roku o zmianie kodeksu karnego i niektórych innych ustaw (Dz.U. z 1990 r. Nr 14, poz. 84).

12 M. Melezini, Założenia polityczno-kryminalne kodeksu karnego z 1969 r. i ich realizacja w praktyce w latach 1970-1980, „Z Dziejów Prawa” 20, 2019, nr 12, s. 901. 
ogólnej ${ }^{13}$ (art. 38 pkt 5 k.k. PRL). Art. 46 k.k. PRL przewidywał kilka podstaw orzeczenia konfiskaty całości albo części mienia. W myśl $§ 1$ art. 46 k.k. PRL konfiskata całości albo części mienia była obligatoryjna w razie skazania za zbrodnie:

- przeciwko podstawowym interesom politycznym lub gospodarczym Polskiej Rzeczypospolitej Ludowej;

— zagarnięcia mienia społecznego znacznej wartości.

Fakultatywna podstawa, uregulowana w art. $46 \S 2$ k.k. PRL, dotyczyła zaś przypadku skazania za inną zbrodnię popełnioną w celu osiągnięcia korzyści majątkowej. Niezależnie zatem od trybu orzekania konfiskaty jej zastosowanie było możliwe tylko w razie popełnienia zbrodni rozumianej jako czyn zagrożony karą pozbawienia wolności na czas nie krótszy od trzech lat albo karą surowszą (art. 5 $\S 2$ k.k. PRL), w dodatku popełniony z winy umyślnej (art. 6 k.k. PRL). Mając jednak na względzie surowość kar w ówczesnym kodeksie, zaznaczyć należy, że zbrodnie stanowiły kategorię szeroką.

Aby przejść do podstaw orzekania obligatoryjnej konfiskaty, w pierwszej kolejności trzeba wyjaśnić rozumienie pojęcia „zbrodnia przeciwko podstawowym interesom politycznym lub gospodarczym Polskiej Rzeczypospolitej Ludowej”. W tym miejscu wskazać należy, że katalog tychże przestępstw został uregulowany w rozdziale XIX k.k. PRL, obejmującym zbrodnie takie jak zdrada ojczyzny, spisek przeciwko Polskiej Rzeczypospolitej Ludowej, szpiegostwo, terroryzm, sabotaż, nadużycie zaufania w stosunkach zagranicznych, dezinformacja, udział w zorganizowanej przestępczości przeciwko gospodarce lub przepisom dewizowym.

Drugą podstawą orzeczenia obligatoryjnej konfiskaty mienia było popełnienie zbrodni polegającej na zagarnianiu mienia społecznego znacznej wartości, spenalizowanej w art. 201 k.k. PRL. Czynność sprawczą, polegającą na zagarnianiu — zgodnie z art. $120 \S 8$ k.k. PRL — rozumiano jako przysporzenie sobie lub komuś innemu korzyści majątkowej przez kradzież, przywłaszczenie albo oszustwo lub inne wyłudzenie. Ustawodawca wyjaśnił także rozumienie pojęcia „mienia społecznego". Zgodnie z art. $120 \S 6$ k.k. PRL pod pojęciem tym należało rozumieć socjalistyczne mienie ogólnonarodowe, mienie spółdzielcze lub mienie innej organizacji ludu pracującego. W opozycji do pojęcia "mienia społecznego" ustawodawca w art. $120 \S 7$ k.k. PRL zdefiniował także termin „mienie cudze”, który oznaczał zarówno cudze mienie osobiste, jak i indywidualne, z tym zastrzeżeniem, iż jeśli mienie takie zostało powierzone instytucji państwowej lub społecznej w celu przechowania, przewozu, sprzedaży, przetworzenia lub w innym podobnym celu, to korzystało ono z takiej samej ochrony jak mienie społeczne. W przeciwieństwie zatem do mienia cudzego mienie społeczne stanowiło własność państwa, ale znajdowało się w posiadaniu jednostek gospodarki uspołecznionej. Uchwycenie różnicy pomiędzy mieniem cudzym a mieniem społecznym nie zawsze było jednak prostym zadaniem, stąd też kwestie sporne w tym zakresie

13 I. Andrejew, Polskie prawo karne w zarysie, Warszawa 1978, s. 265. 
nierzadko rozstrzygała judykatura. Dla przykładu Sąd Najwyższy w wyroku z dnia 14 września 1979 roku, zapadłym w sprawie o sygn. III KR 267/79, stwierdził, że

o charakterze mienia (społecznego, cudzego) decyduje źródło pochodzenia tego mienia i cywilnoprawny stosunek do niego jego posiadacza, zaś zmiana charakteru mienia może nastąpić tylko w wyniku zmiany tego stosunku $\mathrm{w}$ formie prawem przewidzianej wskutek przeniesienia prawa własności (np. w drodze kupna-sprzedaży) ${ }^{14}$.

Znamię w postaci mienia społecznego podlegało zatem określonej wykładni. Kluczowe dla pełnego zrozumienia zakresu tej podstawy orzekania przepadku jest także pojęcie ,znacznej wartości”. Termin ten został poddany kwantyfikacji, określonej w art. $120 \S 9$ k.k. PRL. Wysokość tej kwoty ulegała jednak permanentnym zmianom - w tekście pierwotnym została określona na poziomie wartości przekraczającej 100 tysięcy złotych. Następnie (w drodze ustawy z dnia 26 maja 1982 roku o zmianie niektórych przepisów prawa karnego i prawa o wykroczeniach) kwota ta została podniesiona do wartości przekraczającej 300 tysięcy złotych, a wkrótce potem (w drodze ustawy z dnia 17 czerwca 1988 roku o zmianie niektórych przepisów prawa karnego i prawa o wykroczeniach — Dz.U. z 1988 r. Nr 20, poz. 135) do kwoty 2 milionów złotych. W ten sposób ukształtowana kwota graniczna obowiązywała aż do 28 marca 1990 roku, kiedy konfiskata mienia została wyeliminowana z porządku prawnego. Co istotne, kodeks karny PRL przewidywał także, iż w sytuacji, kiedy zagarnięcia mienia dopuściło się dwóch lub więcej sprawców w porozumieniu, sąd przyjmie za podstawę oceny prawnej czynu ogólną wartość zagarniętego mienia.

\section{Zakres przedmiotowy konfiskaty mienia w kodeksie karnym z 1969 roku}

Zakres omawianej kary dodatkowej — i to orzekanej zarówno w trybie obligatoryjnym, jak i fakultatywnym — był również niezwykle rozległy. Środek ten obejmował mienie należące do sprawcy w chwili wydania wyroku, chociażby nieprawomocnego (art. 47 § 1 in principio). Poszczególne przedmioty lub inne składniki mienia objęte konfiskatą były określane przez sąd ${ }^{15}$, tak więc to właśnie od uznania sądu zależało, czy konfiskacie podlegała część, czy całość mienia spraw$\mathrm{cy}^{16}$. Co istotne, mienie podlegające konfiskacie nie musiało pochodzić z przestępstwa. Orzeczenie tego środka reakcji karnej mogło zatem dotyczyć także mienia zgromadzonego legalnie, które nie zostało nabyte ze środków pochodzących

14 Wyrok SN z 14 września 1979 roku, III KR 267/79, OSNKW 1980, nr 3, poz. 29.

15 K. Łojewski, E. Mazur, Kodeks karny (zestawienie porównawcze przepisów nowego i dawnego kodeksu karnego oraz ustaw szczególnych), „Palestra” 13, 1969, nr 10-11 (142-143), s. 32.

${ }^{16} \mathrm{~K}$. Trybek, Konfiskata rozszerzona mienia pochodzacego z przestepstwa $w$ prawie polskim oraz unijnym, Warszawa 2020, s. 9. 
z działalności przestępczej. Konfiskata obejmowała zarówno mienie ruchome, jak i nieruchomości, wierzytelności oraz wszystkie prawa majątkowe wraz z przynależnościami. Co więcej, kodeks karny PRL nie przewidywał możliwości orzeczenia konfiskaty ułamkowej części lub całości mienia, jak również konfiskaty wszystkich nieruchomości lub wszystkich ruchomości ${ }^{17}$. Zakres konfiskaty mienia nie był także w żadnym stopniu relatywizowany do winy sprawcy. W konsekwencji kara dodatkowa w postaci konfiskaty mienia dotykała nie tylko sprawców przestępstw, lecz także członków rodziny skazanego, niezaangażowanych w przestępczy proceder. Konfiskata mienia była zatem środkiem reakcji prawnokarnej stosowanym wobec osób trzecich, co stało w sprzeczności z elementarną zasadą odpowiedzialności za popełniony czyn, jak również z zasadą indywidualizacji kary. Co więcej, ówcześnie obowiązujące przepisy nie chroniły praw spadkobierców czy współwłaścicieli przed utratą mienia. Osoby te zostały pozbawione możliwości zakwestionowania zasadności orzeczonej konfiskaty mienia, jak również jej zakresu przedmiotowego. Ustawodawca wskazał, co prawda, katalog przedmiotów i praw majątkowych wyłączonych z konfiskaty, niemniej jednak było to mienie pozwalające skazanemu i jego najbliższej rodzinie jedynie na dalszą egzystencję, prowadzoną na najniższym poziomie. Za V. Konarską-Wrzosek wskazać należy, iż zgodnie z art. 161 ustawy z dnia 19 kwietnia 1968 roku — Kodeks karny wykonawczy ${ }^{18}$ (dalej: k.k.w. PRL) oraz art. 8 i 9 ustawy z dnia 17 czerwca 1966 roku o postępowaniu egzekucyjnym w administracji ${ }^{19}$ konfiskacie nie podlegały:

1. przedmioty urządzenia domowego, pościel, bielizna i ubrania codzienne niezbędne dla skazanego i będących na jego utrzymaniu członków jego rodziny, a także ubrania niezbędne do pełnienia służby lub wykonywania zawodu;

2. zapasy żywności i opału niezbędne dla skazanego i będących na jego utrzymaniu członków jego rodziny na okres miesiąca;

3. jedna krowa lub dwie kozy albo trzy owce potrzebne do wyżywienia skazanego i będących na jego utrzymaniu członków jego rodziny, wraz z zapasem paszy i ściółki do najbliższych zbiorów;

4. narzędzia i inne przedmioty niezbędne do osobistej pracy zarobkowej skazanego będącego rzemieślnikiem lub drobnym wytwórcą oraz surowce niezbędne dla niego do jego pracy na okres siedmiu dni;

5. przedmioty niezbędne do pełnienia służby przez skazanego lub do wykonywania przez niego zawodu;

6. w przypadku skazanego, który pobiera periodycznie stałą płacę — pieniądze w kwocie, która odpowiada niepodlegającej egzekucji części płacy (wskazanej w art. $9 \S 1$ ustawy o postępowaniu egzekucyjnym) za czas do najbliższego

17 Ibidem, s. 9-10.

18 Ustawa z dnia 19 kwietnia 1968 roku - Kodeks karny wykonawczy (Dz.U. z 1968 r. $\mathrm{Nr}$ 13, poz. 98).

19 Ustawa z dnia 17 czerwca 1966 roku o postępowaniu egzekucyjnym w administracji (Dz.U. z 1966 r. Nr 24, poz. 151). 
terminu wypłaty, a gdy skazany nie otrzymuje stałej płacy — pieniądze niezbędne dla niego i jego rodziny na utrzymanie przez 14 dni;

7. papiery osobiste, odznaczenia oraz przedmioty niezbędne skazanemu i członkom jego rodziny do nauki lub wykonywania praktyk religijnych, a także przedmioty codziennego użytku, które mogą być sprzedane tylko znacznie poniżej ich wartości, a dla skazanego lub dla członków jego rodziny pozostających z nim we wspólnym gospodarstwie domowym mają znaczną wartość użytkową;

8. niepodjęte wynagrodzenie ze stosunku pracy lub inne należności z tytułu pracy w rolniczej spółdzielni produkcyjnej lub spółdzielni pracy oraz wszystkie świadczenia powtarzające się, których celem jest zapewnienie utrzymania, oraz niepodjęte należności z tytułu dobrowolnego ubezpieczenia rentowego, w granicach minimalnej wysokości miesięcznego wynagrodzenia za pracę najniżej zarabiających pracowników;

9. prawa niezbywalne (czyli na przykład alimenty, stypendia), chyba że możność ich zbycia została wyłączona umową ${ }^{20}$.

\section{Zespół domniemań prawnych}

Konfiskata mienia obowiązująca na gruncie kodeksu karnego z 1969 roku wiązała się także nierozerwalnie z zespołem wzruszalnych domniemań prawnych, uregulowanych w art. $134 \S 1$ i 2 k.k.w. PRL. Zgodnie z tą regulacją w przypadku konfiskaty orzeczonej za przestępstwo popełnione w celu osiągnięcia korzyści majątkowej lub przestępstwo, które wyrządziło szkodę w mieniu społecznym, stosowano następujące ułatwienia procesowe:

1. domniemanie, że do oskarżonego lub skazanego należą rzeczy znajdujące się $\mathrm{w}$ samoistnym posiadaniu osoby będącej w bliskim $\mathrm{z}$ nim stosunku oraz przysługujące tej osobie prawa majątkowe, chyba że były one co najmniej od roku przed popełnieniem przestępstwa w jej samoistnym posiadaniu (art. $134 \S 1$ k.k.w. PRL);

2. domniemanie, że rzeczy oraz prawa majątkowe, które były we władaniu skazanego po orzeczeniu tej kary, należały do niego już w czasie popełnienia przestępstwa (art. $134 \S 2$ k.k.w. PRL).

W myśl art. 136 k.k.w. PRL powyższych domniemań nie stosowano po upływie pięciu lat od odbycia przez skazanego kary pozbawienia wolności lub jej darowania, a w każdym razie po upływie dziesięciu lat od daty popełnienia przestępstwa. Zgodnie z art. $137 \S 1$ k.k.w. PRL domniemania ustanowione w art. 134 mogły zostać obalone - przynajmniej teoretycznie — w drodze powództwa przeciwko Skarbowi Państwa. W tym celu należało jednak wykazać źródła nabycia

20 V. Konarska-Wrzosek, J. Lachowski, Przepadek $i$ konfiskata mienia w Kodeksie karnym z 1969 r., [w:] eidem, Instytucja przepadku w polskim prawie karnym, Warszawa 2020. 
konkretnego mienia, jak również pochodzenie środków, które pozwoliły na owo nabycie. Oskarżony musiał zatem przedstawić przeciwdowód niosący wiarygodną informację o pochodzeniu majątku, co świadczy o zastosowaniu przez ustawodawcę odwróconego ciężaru dowodu (reverse burden of proof) i tym samym złamaniu zasady in dubio pro reo.

\section{Ratio legis konfiskaty mienia w kodeksie karnym z 1969 roku}

Oficjalnym powodem wprowadzenia konfiskaty mienia do kodeksu karnego PRL była potrzeba ochrony interesów politycznych i gospodarczych Polskiej Rzeczypospolitej Ludowej, jak również mienia społecznego (które w ówczesnym okresie podlegało znacznie silniejszej ochronie niż mienie prywatne ${ }^{21}$ ) oraz odstraszanie potencjalnych sprawców przestępstw wymierzonych w te dobra. Szerokie spektrum stosowania konfiskaty mienia, jak również rozległy zakres przedmiotowy jej orzekania oraz obligatoryjny charakter świadczą jednakże o wadze przywiązywanej przez władze Polskiej Rzeczypospolitej Ludowej do konfiskaty jako elementu gry politycznej przeciwko społeczeństwu ${ }^{22}$. Na powyższe wskazuje także fakt, iż konfiskata mienia pod rządami kodeksu karnego PRL nie była w żadnym stopniu powiązana z wysokością szkody wyrządzonej przestępstwem, a zakresu orzekanej konfiskaty nie relatywizowano do rozmiarów przestępstwa. Poza podstawą fakultatywną orzekania tego środka reakcji prawnokarnej nie miało także znaczenia, czy sprawca działał w celu osiągnięcia korzyści majątkowej, czy też nie. Tym samym stwierdzić należy, że konfiskata mienia na gruncie kodeksu karnego PRL w żadnym razie nie opierała się na zasadzie współmierności. Idąc dalej, za A. Spotowskim stwierdzić należy, że „o jej zakresie przedmiotowym nie decydowała waga popełnionego przez skazanego przestępstwa, ale kwestia tego, czy posiadał on mienie, jakich rozmiarów i jakiej wartości" 23 . Powyższe prowadzi do konstatacji, że ukrytym celem kary dodatkowej konfiskaty mienia było zadanie sprawcy (jak również jego rodzinie) odpowiednio dotkliwej kary, godzącej w jego stan majątkowy. Konfiskata mienia pod rządami kodeksu karnego PRL była zatem karą o typowo represyjnym charakterze, nierzadko mającym na celu zniszczenie przeciwników politycznych komunistycznej władzy ${ }^{24}$.

21 A. Malicka, M. Sikora, Prawnokarna ochrona własności, „Wrocławskie Studia Erazmiańskie. Studia Erasmiana Wratislaviensia" 2009, z. 3, s. 367.

22 I. Rzeplińska, Polityka stosowania kary konfiskaty mienia w PRL, „Archiwum Kryminologii PAN" 18, 1992, s. 147 n.

23 A. Spotowski, Konfiskata mienia i przepadek rzeczy (uwagi de lege ferenda), „Państwo i Prawo" 1989, z. 3, s. 102.

24 I. Rzeplińska, Sprawcy i kara..., Warszawa 2017, s. 75. 


\section{Konkluzja}

Konfiskata mienia obowiązująca na gruncie kodeksu karnego PRL była jedną z najcięższych i najczęściej stosowanych ${ }^{25}$ kar majątkowych. Pozwalała ona na eliminację niezależności średniej klasy ekonomicznej, jak również stanowiła narzędzie do walki z przeciwnikami politycznymi. Trudno uznać ją za karę słuszną, zwłaszcza w kontekście tego, że dotykała ona nie tylko samego sprawcę, lecz także jego najbliższych ${ }^{26}$. Szeroki zakres zastosowania tejże regulacji, w powiązaniu z odwróceniem ciężaru dowodu oraz zespołem domniemań prawnych, spowodował, że konfiskata mienia stanowiła bardzo niebezpieczny instrument. $Z$ perspektywy dzisiejszych standardów ochrony praw człowieka instytucję tę jednoznacznie należy ocenić negatywnie jako zbyt restrykcyjną, naruszającą podstawowe zasady procesu karnego, a także służącą do umacniania władzy komunistycznej oraz do walki z opozycją ${ }^{27}$. O represyjności i niezasadności tego środka świadczy fakt, iż spadkobiercy bezprawnie pozbawionego mienia - mimo prawomocnych uchyleń wyroków skazujących na konfiskatę zapadłych w PRL — do dziś podejmują mozolne próby odzyskania nielegalnie zabranego im mienia ${ }^{28}$. Z tych też powodów odejście od instytucji konfiskaty mienia rozumianej jako odebranie sprawcy przestępstwa całości lub części mienia niezależnie od legalności jego pochodzenia, a także w oderwaniu od rozmiarów szkody, było konieczne.

\section{Bibliografia}

Andrejew I., Polskie prawo karne w zarysie, Warszawa 1978.

Buczkowski K., Skuteczność odzyskiwania korzyści majątkowych uzyskanych przez sprawców przestępstwa - analiza przepadków orzeczonych na podstawie art. 45 k.k., „Prawo w Działaniu” 2010, $\mathrm{nr} 8$.

Cieślak W., Marek A., Oczkowski T., Raglewski J., [w:] System prawa karnego, t. 6. Kary i inne środki reakcji prawnokarnej, red. M. Melezini, Warszawa 2016.

Konarska-Wrzosek V., Lachowski J., Przepadek i konfiskata mienia w Kodeksie karnym z 1969 r., [w:] V. Konarska-Wrzosek, J. Lachowski, Instytucja przepadku w polskim prawie karnym, Warszawa 2020.

Łojewski K., Mazur E., Kodeks karny (zestawienie porównawcze przepisów nowego i dawnego kodeksu karnego oraz ustaw szczególnych), „Palestra” 13, 1969, nr 10-11 (142-143).

25 Jak wskazuje V. Konarska- Wrzosek ,od 1985 r. była to druga co do częstotliwości orzekania kara dodatkowa, której udział wynosił 1/6 wszystkich orzekanych kar dodatkowych”. Zob. V.Konarska-Wrzosek, J. Lachowski, op. cit.

26 I. Rzeplińska, Polityka stosowania kary konfiskaty mienia..., s. 147 n.

27 K. Polit-Langierowicz, Rozszerzony przepadek korzyści pochodzacych z przestępstwa uwagi do projektu nowelizacji Kodeksu karnego, „Prokuratura i Prawo” 2008, nr 7-8, s. 157.

28 Jedną z takich spraw jest walka spadkobiercy osoby skazanej w ramach tak zwanej afery mięsnej, nadzorowana przez Helsińską Fundację Praw Człowieka w ramach Programu Spraw Precedensowych — więcej na ten temat: https://www.hfhr.pl/postepowanie-w-sprawie-mienia-skonfiskowanegow-prl-w-sprawie-afery-miesnej-2/ (dostęp: 10.06.2021). 
Makowski W., Prawo karne. Część ogólna. Wykład porównawczy prawa karnego austrjackiego, niemieckiego i rosyjskiego obowiązującego w Polsce, Warszawa 1920.

Malicka A., Sikora M., Prawnokarna ochrona własności, „Wrocławskie Studia Erazmiańskie. Studia Erasmiana Wratislaviensia” 2009, z. 3.

Melezini M., Założenia polityczno-kryminalne kodeksu karnego z 1969 r. i ich realizacja w praktyce w latach 1970-1980, „Z Dziejów Prawa” 20, 2019, nr 12.

Polit-Langierowicz K., Rozszerzony przepadek korzyści pochodzących z przestępstwa - uwagi do projektu nowelizacji Kodeksu karnego, ,Prokuratura i Prawo” 2008, nr 7-8.

Postulski K., Siwek M., Przepadek w polskim prawie karnym, Warszawa, 2004.

Przepadek przedmiotów i korzyści pochodzacych z przestęstwa, red. E.M. Guzik-Makaruk, Warszawa 2012.

Rzeplińska I., Konfiskata mienia. Studium z historii polityki kryminalnej, Warszawa 1997.

Rzeplińska I., Polityka stosowania kary konfiskaty mienia w PRL, „Archiwum Kryminologii PAN” $18,1992$.

Rzeplińska I., Sprawcy i kara. Skazani w PRL na karę konfiskaty mienia, „Biuletyn PTK” 2017, nr 24.

Spotowski A., Konfiskata mienia i przepadek rzeczy (uwagi de lege ferenda), „Państwo i Prawo” 1989, z. 3.

Trybek K., Konfiskata rozszerzona mienia pochodzacego z przestępstwa w prawie polskim oraz unijnym, Warszawa 2020.

\section{Orzecznictwo}

Wyrok SN z 14 września 1979 roku, III KR 267/79, OSNKW 1980, nr 3, poz. 29.

\section{Źródła internetowe}

https://www.hfhr.pl/postepowanie-w-sprawie-mienia-skonfiskowanego-w-prl-w-sprawie-aferymiesnej-2/. 